\title{
Development of a new experimental model of intramuscular electrical stimulation of the diaphragm in rabbits ${ }^{1}$
}

\author{
Desenvolvimento de um novo modelo experimental de estimulação elétrica intramuscular do \\ diafragma em coelhos
}

\author{
Rodrigo Guellner Ghedini ${ }^{\mathrm{I}}$, Ane Margarites ${ }^{\mathrm{II}}$, Elaine Aparecida Felix ${ }^{\mathrm{III}}$, Rogério Gastal Xavier ${ }^{\mathrm{IV}}$, Cristiano Feijó Andrade ${ }^{\mathrm{V}}$ \\ I Physiotherapist, Porto Alegre Santa Casa, Researcher at airway and lung laboratory, HCPA, Porto Alegre-RS, Brazil.

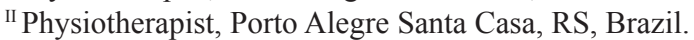 \\ ${ }^{\text {III }}$ PhD, Associate Professor of Anesthesiology, Department of Surgery, Federal University of Rio Grande do Sul (UFRGS), Porto Alegre-RS, Brazil. \\ ${ }^{\text {IV }} \mathrm{PhD}$, Associate Professor of Pneumology, Department of Internal Medicine, UFRGS, Porto Alegre-RS, Brazil. \\ ${ }^{v} \mathrm{PhD}$, Thoracic Surgeon, HCPA, Santo Antônio Children's Hospital, Porto Alegre-RS, Brazil.
}

\begin{abstract}
Purpose: To develop an animal model of diaphragmatic electrical stimulation able to generate an appropriate ventilatory support through the direct implantation of electrodes in the diaphragm (electroventilation). Methods: Six New Zealand female rabbits (2-3 kg) were placed on mechanical ventilation. Then, a laparotomy was performed in order to identify the motor points in each hemidiaphragm, followed by the implantation of the electrodes for diaphragmatic stimulation. We tested two types of electrodes according to the conduction of electrical stimulation: unipolar and bipolar. The electrodes were placed on different occasions in the same animals and tested with current intensities of 20,26 and $32 \mathrm{~mA}$. Each current intensity was repeated three times for 10 respiratory cycles with 1 minute interval between each cycle, and 5 minutes for new current intensity. We recorded the relationship between current intensity and inspiratory volume. Results: The electrodes adequately stimulate the diaphragm and obtain inspired volumes using different intensity currents. The bipolar electrode generated inspiratory volumes as high as 4.5 times of baseline while the unipolar electrode reached up to 3.5 times of baseline. Conclusion: This model has proved to be effective for studying the performance of the diaphragm under different electrical stimulations using different set of electrodes.
\end{abstract}

Key words: Electric Stimulation. Diaphragm. Pulmonary Ventilation. Rabbits.

\section{RESUMO}

Objetivo: Desenvolver um modelo animal de estimulação elétrica diafragmática capaz de gerar um suporte ventilatório adequado através da implantação direta de eletrodos no diafragma (eletroventilação). Métodos: Seis coelhas da raça Nova Zelândia (2-3 kg) foram colocadas em ventilação mecânica. Através de uma laparotomia foram identificados os pontos motores em ambas as cúpulas diafragmáticas, seguido pela implantação dos eletrodos para estimulação diafragmática. Foram testados dois tipos de eletrodos de acordo com a condução do estímulo elétrico: unipolar e bipolar. Os eletrodos foram posicionados em diferentes ocasiões nos mesmos animais e testados com intensidades de corrente de 20, 26 e $32 \mathrm{~mA}$, sendo cada uma delas repetidas três vezes durante 10 ciclos respiratórios com intervalo de 1 minuto entre cada ciclo e repouso de 5 minutos para nova intensidade de corrente. Foram registradas a relação entre a intensidade de corrente e o volume de ar inspirado. Resultados: Os eletrodos estimularam adequadamente o diafragma com um volume de ar inspirado até 4,5 vezes maior no modo bipolar e de 3,5 vezes no modo unipolar em relação à linha de base. Conclusão: Este modelo demonstrou ser efetivo para o estudo do desempenho do diafragma sob diferentes estimulações elétricas e diferentes tipos de eletrodos.

Descritores: Estimulação Elétrica. Diafragma. Ventilação Pulmonar. Coelhos.

${ }^{1}$ Research performed at Animal Experimentation Unit Research Center, airway and lung laboratory, Clinics Hospital of Porto Alegre (HCPA), RS, Brazil.

\section{Introduction}

Trauma is the leading cause of death worldwide among young people. In Brazil, it is believed that there are 130,000 deaths annually due to trauma and about 450,000 patients with severe sequelae $^{1-2}$. Many trauma patients have different types of sequelae such as damage of the central nervous system or spinal cord injuries. Patients with spinal cord injuries due to high cervical trauma (C1-C5) have tetraplegia and impaired diaphragmatic function, losing their ability to breathe spontaneously. Other neuromuscular diseases such as Amyotrophic Lateral Sclerosis also lead to a progressive impairment of diaphragmatic function 
resulting in poor quality of life and the need for permanent ventilatory support. These incapacitated patients usually require hospitalization in specialized centers or in homes adequately prepared for this purpose $\mathrm{e}^{3}$. The possibility of electrical activation of the diaphragm with electrodes placed on this muscle (electroventilation) is an alternative for individuals dependent on mechanical ventilation and without any expectation of weaning. Therefore, there is a general interest in studies to develop new methods and devices for diaphragmatic pacing in order to provide better quality of live for such patients.

In this study, we demonstrate the development of a new animal model by electrical stimulation of the diaphragm through electrodes implanted directly into this respiratory muscle.

\section{Methods}

Six New Zealand female rabbits were used, weighing between 2 and $3 \mathrm{~kg}$. All animals were treated according to the Ethical Code for Animal Experimentation from the World Health Organization $^{16}$. The study was approved by the Committee on Ethics in Research of the Clinics Hospital of Porto Alegre under number 07-133. The animals received standard intramuscularly premedication with ketamine hydrochloride $(20 \mathrm{mg} / \mathrm{kg})$, midazolam $(0.2 \mathrm{mg} / \mathrm{kg})$ and atropine $(0.025 \mathrm{mg} / \mathrm{kg})$, followed by trichotomy and peripheral venous access. Anesthesia was induced with propophol (4 mg/kg), to be maintained with an intravenously continuous infusion of propophol $(11 \mathrm{mg} / \mathrm{kg} / \mathrm{h})$ and remiphentanyl $(0.3 \mathrm{ml} / \mathrm{kg} / \mathrm{min})$. The animals were intubated orally and placed on mechanical ventilation (Nikkei-Takaoka, Sao Paulo, Brazil). For flow signal and tracheal pressure acquisition, two single sensors were connected at the end of the endotracheal tube (Hans
Rudolph - Kansas City - USA) and attached to a pressure system acquisition, MVR 16X (Universidad de la Republica, Montevideo, Uruguay).

After hemodynamic stabilization, the animal inspiratory volume was measured at baseline. A laparotomy was performed for visualization of the diaphragm (Figure 1A), followed by identification of motor points (Figure 1B). The electrodes were then fixed to the motor points (Figure 1C), and they were connected to a generator of electric current (Dualpex 961, Phrenics, Quark Medical, Sao Paulo, Brazil). They produced a depolarized current with the following characteristics: rectangular waveform, alternating symmetrical pulse, frequency of $25 \mathrm{HZ}$ and burst width of 0.07 milliseconds. The abdomen wall was then sutured leaving space only to the conducting wires (Figure 1D). In order to deliver an induced apnea, the minute volume was increased gradually to reach a $\mathrm{CO}_{2}$ blood concentration around $17 \mathrm{mmHg}$.

We evaluated the responses with two different sets of unipolar and bipolar electrodes. One single channel electrode (unipolar) was sutured on the muscular portion of each hemidiaphragm, promoting simultaneous contraction of both hemidiaphragms. The bipolar set consisted of one pair of electrodes implanted in the same hemidiaphragm which could generate independent contractions. To evaluate the performance from the unipolar and bipolar sets, we compared the relationship between different current intensities and the generated inspired volume respectively. The two set of electrodes were positioned in the same animal at different periods during the same experiment. The current intensities used were 20,26, and $32 \mathrm{~mA}$ to be sustained for 10 respiratory cycles. Each different intensity records were made in three separate periods with one minute interval. The baseline inspiratory volume was assessed with the animal in supine position.
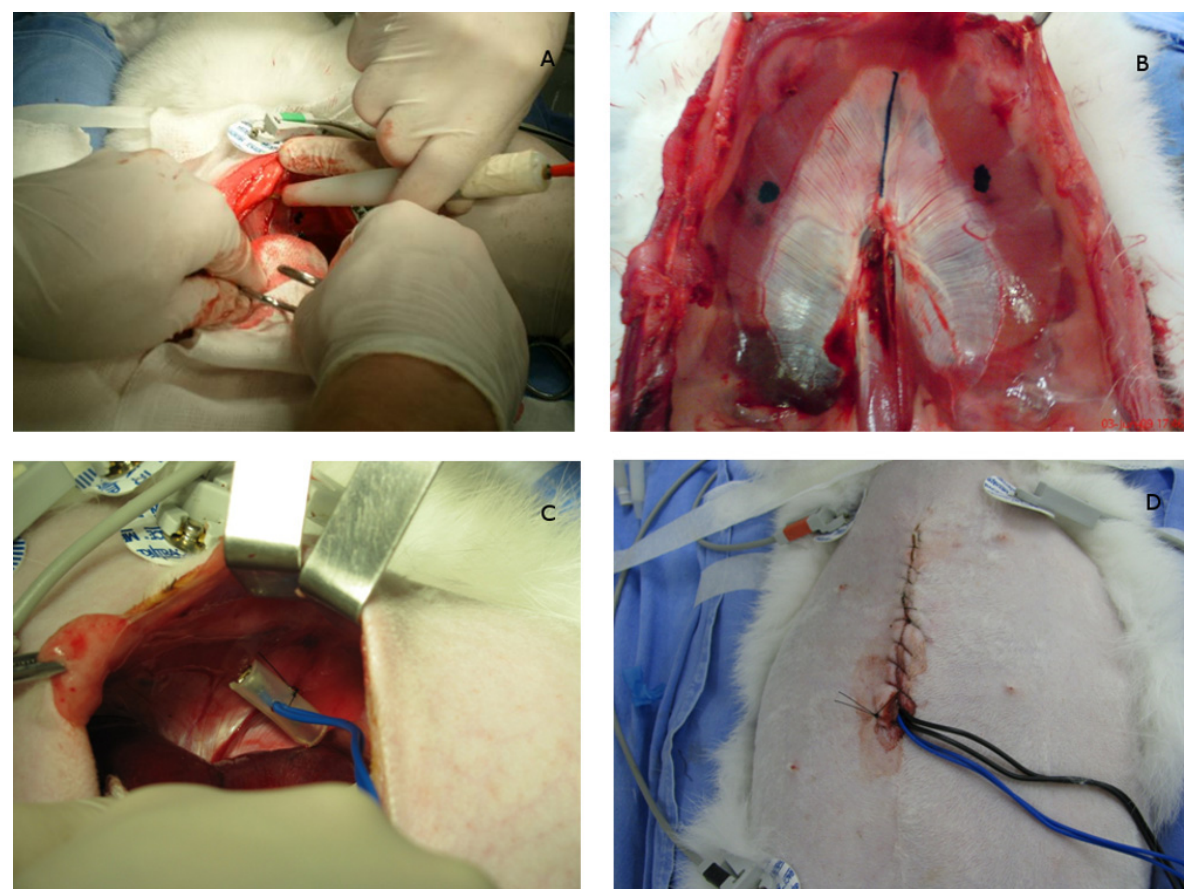

FIGURE 1 - Electric stimulation of the diaphragm: A) seeking the diaphragmatic motor points; B) location of motor points (dark circles); C) bipolar electrode implanted on the right diaphragmatic motor point and $\mathbf{D}$ ) abdomen closed with the external wire electrodes 


\section{Results}

In four animals we were unable to record the inspiratory volume due to unilateral or bilateral pneumothorax and/or fluid accumulation in the abdominal cavity which interfered in transmission of the electrical stimulation. In two animals, the unipolar (one channel) and bipolar (two channel) electrodes were able to adequately stimulate the diaphragm and obtain inspired volumes using current intensities of 20,26 and $32 \mathrm{~mA}$. The bipolar electrode generated inspiratory volumes as high as 4.5 times of the baseline while the unipolar electrode reached up to 3.5 times of baseline. Since the volumes obtained were much higher than the baseline, we then added to the protocol the current intensities of 10 and $16 \mathrm{~mA}$ seeking volumes closer to the physiological pattern. The results from two animals are shown in the Figure 2.

\section{Inspiratory Volume (animal \#1)}
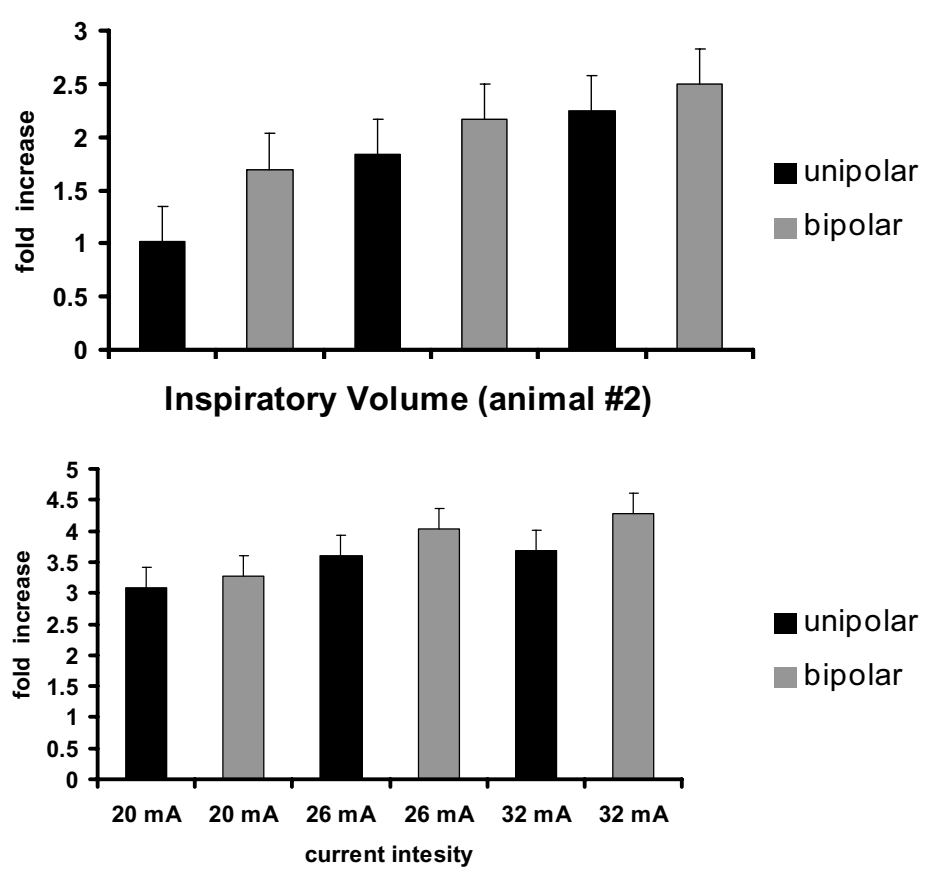

FIGURE 2 - Inspiratory volumes from two animals obtained in Unipolar modes (one channel for the two diaphragmatic cupules) and bipolar (two channels, one for each diaphragmatic cupule) at current intensities of 20 , 26 and $32 \mathrm{~mA}$. The values are expressed as fold increase of baseline. The errors bars represent the standard error of the different current intensities recorded in three separate periods with one minute interval

\section{Discussion}

The use of electrical currents to produce artificial ventilation has been described since the nineteenth century through the generation of action potentials either on the nerve and/or on the diaphragm or any other ventilatory muscles throughout different techniques ${ }^{4-7}$. Several methods comparing stimulation through the phrenic nerve and ventilatory muscles have been tested, showing similar results in the generation of transdiaphragmatic pressure and speed nerve latency ${ }^{7}$.
The first studies of electroventilation were performed by stimulating the phrenic nerve in the neck or its path into the chest, in order to trigger action potentials ${ }^{8}$. This technique has proven to be clinically effective, but due to the extensive mobility of the cervical region, there were significant limitations and risks especially on the phrenic nerve path, increasing the risk of mechanical nerve damage. The implantation of electrodes directly into the diaphragm muscle seems to be a feasible and reproducible technique for animal studies and clinical trials so far undertaken. Peterson et al. ${ }^{11}$ studying the positioning of monopolar electrodes on diaphragm of dogs observed that was possible the activation of the diaphragmatic muscle using intramuscular electrodes. In this study, they obtained lung volumes up $167 \%$ from baseline, without inducing any muscle fatigue ${ }^{11}$. In another study, this same group could demonstrate the safety and reliability of intramuscular diaphragm stimulation through monopolar electrodes. Using five dogs which received electrical stimulation for $61-183$ days ${ }^{17}$, the authors did not observe any muscle tissue damage as a result of the presence of the electrode, and any negative side effects as well as on the heart or the lung function. Immunohistochemistry studies suggested transformation of the diaphragm muscle fibers to type I, which have better capacity to resist fatigue, leading to the conclusion that this technique would present minimal risk of phrenic injury in human patients ${ }^{13}$.

In one of the first electroventilation clinical descriptions, one 35 years-old male victim of high cervical trauma making dependable of permanent mechanical ventilation was submitted to a laparotomy for intramuscular insertion of monopolar electrodes in the diaphragm. After such procedure, it was possible to reach an inspired volume of $380 \mathrm{ml}$ when the left hemidiaphragmatic was stimulated with a current strength of $25 \mathrm{~mA}$. Nevertheless, the volume of the right hemidiaphragm was less than $100 \mathrm{ml}$, suggesting that the right electrode was not properly positioned on the motor point. After new surgical procedure with appropriate fixation of the electrodes, a period of 20 weeks was required for diaphragmatic training and adaptation, resulting in maximum inspired volume of $1.120 \mathrm{ml}$ with a current strength of $25 \mathrm{~mA}^{15}$

Over the years, there has been a major breakthrough in technological development of new devices for electroventilation, which provided an important step toward creation of diaphragmatic pacemakers, placed through electrodes implanted directly on the diaphragm by laparotomy ${ }^{9-10}$. Despite displaying similar physiological response to nerve phrenic stimulation, this intramuscular technique showed to be less difficult to proceed in terms of muscle preparation and implantation ${ }^{11-12}$.

The full activation of the diaphragm depends on the proper implantation of electrodes on the diaphragm motor points, which represents the muscle area where the branches of the phrenic nerve penetrate into the diaphragm. A minimal amount of electrical stimulation should be necessary to cause full muscle contraction ${ }^{13-}$ ${ }^{15}$. Specific anatomical landmarks of the diaphragm are usually used to place the electrodes, since the phrenic nerve branches are not readily identified on the bottom edge of the diaphragm ${ }^{11}$.

Ventilation with the use of electrical currents is supposed to be more physiological than mechanical ventilation because patients can keep using their own inspiratory muscles to inflate the lungs. On the other hand, there are many technical difficulties 
applying this technique, since it is necessary the full control over the muscle intended to be stimulated without interfering other organs function.

In our experiments, one of the major problems remains the difficulty to achieve appropriate identification of the diaphragmatic motor points. Furthermore, it is still a challenge the design of a specific electrode for diaphragmatic stimulation since many epimysial electrodes are designed for intramuscular stimulation, but not particularly for the diaphragm which is much thinner and delicate in comparison to skeletal muscle ${ }^{18}$. In our opinion, the current generator is also an unsolved problem, because the ideal device should have the ability to generate a reliable electric current of low power consumption in order to provide satisfactory security, mobility and certain autonomy.

\section{Conclusion}

This model has proved to be effective for studying the performance of the diaphragm under different electrical stimulations using different set of electrodes.

\section{References}

1. Organization WH. WHO Statistical Information System (WHOSIS). 2009 [cited 2010 April 01]. Available from: http://www.who.int/whosis/ indicators/WHS09 IndicatorCompendium 20090701.pdf

2. Saúde Md. Secretaria de Vigilância em Saúde. 2008-01 [updated 2008; cited 2010 April 22]. Available from: http://tabnet.datasus.gov.br/cgi/ tabcgi.exe?idb2008/c09.def.

3. McCluskey L. Amyotrophic lateral sclerosis: ethical issues from diagnosis to end of life. NeuroRehabilitation. 2007;22(6):463-72.

4. Glenn WW, Holcomb WG, Gee JB, Rath R. Central hypoventilation; long-term ventilatory assistance by radiofrequency electrophrenic respiration. Ann Surg. 1970;172(4):755-73.

5. Geddes LA, Voorhees WD, Babbs CF, Deford JA. Electroventilation. Am J Emerg Med. 1985;3(4):337-9.
6. Geddes LA, Voorhees WD, Lagler R, Riscili C, Foster K, Bourland JD. Electrically produced artificial ventilation. Med Instrum. 1988;22(5):263-71. 7. Geddes LA. Electroventilation — a missed opportunity? Biomed Instrum Technol. 1998;32(4):401-14.

8. Sarnoff SJ, Hardenbergh E, Whittenberger JL. Electrophrenic respiration. Am J Physiol. 1948;155(1):1-9.

9. Aiyar H, Stellato TA, Onders RP, Mortimer JT. Laparoscopic implant instrument for the placement of intramuscular electrodes in the diaphragm. IEEE Trans Rehabil Eng. 1999;7(3):360-71.

10. Onders RP, Elmo M, Khansarinia S, Bowman B, Yee J, Road J, Bass B, Dunkin B, Ingvarsson PE, Oddsdóttir M. Complete worldwide operative experience in laparoscopic diaphragm pacing: results and differences in spinal cord injured patients and amyotrophic lateral sclerosis patients. Surg Endosc. 2009;23(7):1433-40.

11. Peterson DK, Nochomovitz M, DiMarco AF, Mortimer JT. Intramuscular electrical activation of the phrenic nerve. IEEE Trans Biomed Eng. 1986;33(3):342-51.

12. DiMarco AF, Supinski GS, Budzinska K. Inspiratory muscle interaction in the generation of changes in airway pressure. J Appl Physiol. 1989;66(6):2573-8.

13. Peterson DK, Nochomovitz ML, Stellato TA, Mortimer JT. Long-term intramuscular electrical activation of the phrenic nerve: safety and reliability. IEEE Trans Biomed Eng. 1994;41(12):1115-26.

14. Dunn RB, Walter JS, Walsh J. Diaphragm and accessory respiratory muscle stimulation using intramuscular electrodes. Arch Phys Med Rehabil. 1995;76(3):266-71.

15. DiMarco AF, Onders RP, Kowalski KE, Miller ME, Ferek S, Mortimer JT. Phrenic nerve pacing in a tetraplegic patient via intramuscular diaphragm electrodes. Am J Respir Crit Care Med. 2002;166(12 Pt 1):1604-6.

16. Howard-Jones N. A CIOMS ethical code for animal experimentation. WHO Chron. 1985;39(2):51-6.

17. Peterson DK, Nochomovitz ML, Stellato TA, Mortimer JT. Long-term intramuscular electrical activation of the phrenic nerve: efficacy as a ventilatory prosthesis. IEEE Trans Biomed Eng. 1994;41(12):1127-35.

18. Schmit BD, Mortimer JT. The effects of epimysial electrode location on phrenic nerve recruitment and the relation between tidal volume and interpulse interval. IEEE Trans Rehabil Eng. 1999;7(2):150-8.

\section{Correspondence:}

Cristiano Feijó Andrade

Hospital de Clínicas de Porto Alegre

Serviço de Cirurgia Torácica

Ramiro Barcelos, 2.350

90035-903 Porto Alegre - RS Brasil

Phone: (55 51)3359-8684

Fax: (55 51)3359-8884

cristianofa@,cirurgiatoracica.net

Conflict of interest: none

Financial source: FIPE at HCPA

Review: May 11, 2010

Accepted: June 15, 2010

\section{How to cite this article}

Ghedini RG, Margarites A, Felix EA, Xavier RG, Andrade CF. Development of a new experimental model of intramuscular electrical stimulation of the diaphragm in rabbits. Acta Cir Bras. [serial on the Internet] 2010 Nov-Dec;25(6). Available from URL: http:// $\underline{\text { www.scielo.br/acb }}$ 